\title{
Effect of Land Use on Ground Water Quality (A Case Study from Ciracas Sub District, East Jakarta, Indonesia)
}

\author{
Lily Surayya Eka Putri, Nelly Kustanti, and Etyn Yunita, Member, IACSIT
}

\begin{abstract}
Most of Ciracas society as a rural area had given a complain of worst groundwater that occured metally odour dan yellowish colour. To know the quality of groundwater of that it was conducted the research indicated by the existing of feacal Coliform and concentration of Fe and Mn. There were 5 villages as sites of sampling (Ciracas, Susukan, Kampung Rambutan, Kelapa Dua Wetan, and Cibubur Bekasi) where each locations was differed from the use to rice field, swamp, and garden. Microbial and chemical data were collected at each sites from 15 wells with three replications. Data were analyzed by One Way Anova to compare each locations with different land uses and concentration of $\mathrm{Fe}$ and $\mathrm{Mn}$, and microbial data. Pearson's Correlation method was also used to analyze correlation between septic tank distance and concentration of Coliform and $E$. coli. The results showed that most of the groundwater surrounding Ciracas sub-district had been contaminted by Coliform and Escherichia coli ranging from 0 to 26.000 MPN/100 $\mathrm{ml}$ and 0 to $6790 \mathrm{MPN} / 100 \mathrm{ml}$, excluded Susukan village which was used to rice field, and this was significantly different at study sites in each land uses $(p<0.05)$. Nevertheless, well depth and distance of septic tank to well were not significantly correlated with concentration of Coliform and E. coli $(p>0.05)$. Swamp sites indicated high amount of $\mathrm{Fe}$, more than $0,3 \mathrm{ppm}$ and for the used to rice field showed less amount of $\mathrm{Mn}(<0,1 \mathrm{ppm})$. Nevertheless, based on statistical results showed that there was no significant differences in concentration of $\mathrm{Fe}$ and $\mathrm{Mn}$ in different land uses at study sites $(p>0.05)$ and also no correlation with well depth significantly $((p>0.05)$. Refer to DHMI No. 907/2002 about drinking water standard, it could be said that most of groundwater in Ciracas sub-district was not able to be used as drinking water. It is needed pre-treatment to drinkable.
\end{abstract}

Index Terms-Bioindicator, coliform, escherichia coli, iron and manganese, well water,

\section{INTRODUCTION}

Generally, the source of drinking water in Indonesia comes from surface water, groundwater and rain water, and groundwater is the mayor drinking water source [1]. Different sources of drinking water will cause different composition of water [2]. Globally, the quantity of water resource on earth is relatively constant while the quality has declined due to pollution.

The likelihood of groundwater contamination by the

Manuscript received October 16, 2012; revised December 7, 2012.

L. S. E. Putri is now with the Department of Biology, Faculty of Science and Technology, State Islamic University Syarif Hidayatullah Jakarta, Indonesia (e-mail: lily.surayya@uinjkt.ac.id).

N. Kustanti was with the Department of Biology, Faculty of Science and Technology, State Islamic University Syarif Hidayatullah Jakarta, Indonesia.

E. Yunita was with the Environmental laboratory of State Islamic University Syarif Hidayatullah Jakarta, Indonesia (e-mail: etyn.yunita@)uinjkt.ac.id). sewage disposal system systems is greatest where septic systems are closely spaced as in subdivided tracts in suburban areas and in areas where the bedrock is covered by little or no soil. Fecal bacteria, including Coliform and Escherischia coli, are mostly contaminated groundwater and further these are used as a biomonitoring tool for drinking water quality [3]. Fecal coliform bacteria are present in the gastrointestinal tract of humans and other warm-blooded animals. The presence of these bacteria in natural water indicates degradation by human or animal waste and may be related to septic tank waste.

Monitoring conducted by National Environmental Management Institution [4] in 75 wells in 2004-2005 was reported that groundwater surrounding Jakarta had high organic and inorganic pollutants. As a result, groundwater in Jakarta had no longer appropriate with water quality standard, especially for drinking water. At East Jakarta district, $45 \%$ of groundwater had been contaminated by fecal Coliform and $80 \%$ of E. coli. The same condition was also found at South Jakarta district that E. coli bacteria from septic tank effluent had contaminated most of ground water in range from 3-160 MPN/100 $\mathrm{ml}$ [5]. This was due to the dense of population which causes the location of wells was much closer to the septic tank systems [5]-[7].

In Ciracas sub-district, most of houses are adjacent to one another where the septic systems are certainly near the neighbor's wells. Moreover, the former land use in Ciracas sub-district were mostly swamp, rice field, and garden where were assumed causing in pollution problem in ground water by inorganic compounds. The Residents surrounding Ciracas sub-district are still using groundwater as drinking water source until now. Lately, there have been many complains from the residents due to bad quality of groundwater which was yellowish and smelling like iron. Therefore, it is necessary to analyze the ground water quality related to the former land uses and septic system.

\section{MATERIALS AND METHOD}

This study was conducted at 5 villages in Ciracas subdistrict, East Jakarta district, Indonesia in of Ciracas subdistrict, that were Susukan, Kampung Rambutan, Kelapa Dua Wetan, and Cibubur villages (Figure 1) and each villages was divided into 3 types of former land use (swamp, rice field, and garden). Ground water samples collected in 2009 from domestic wells were analyzed for concentration of iron and manganese, and also fecal bacteria, that were Coliform and E. coli, with 3 replications.

Measurement of physical parameters (pH and temperature) were conducted in situ, whereas for concentration of $\mathrm{Fe}$ and $\mathrm{Mn}$ and microbiological test were 
conducted in laboratory using the standard method. Concentration of iron and manganese were analyzed using AAS (atomic absorption spectrophotometry) to measure the absorbance. Total Coliform and E. coli bacteria were measured using the MPN (Most Probably Number) method which was conducted on 3 stages of analysis, that were determination of MPN presumptive Coliform/100 $\mathrm{ml}$ of water, determination of MPN faecal Coliform $/ 100 \mathrm{ml}$ of water and determination of MPN E. coli/100 ml of water. The media used to analyze the fecal bacteria was lactose broth with 4 dilutions of water samples: $10^{-1}, 10^{-2}, 10^{-3}, 10^{-4}$, then all samples in Durham tubes were incubated $37^{\circ} \mathrm{C}$ for 24 hours for $E$. coli analysis and 48 hours for Coliform analysis. Determination of MPN is determined by matching the results with the table.
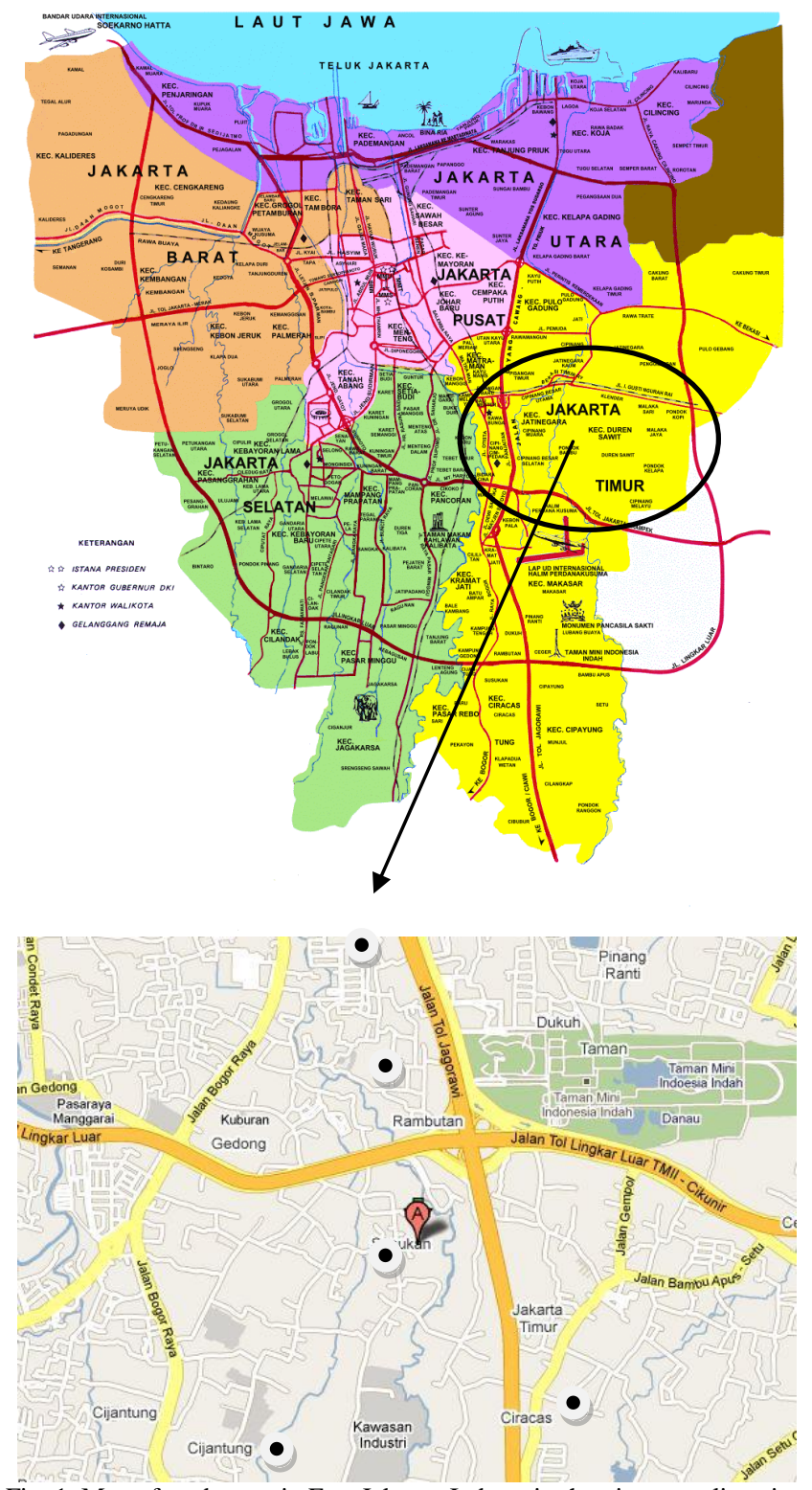

Fig. 1. Map of study area in East Jakarta, Indonesia showing sampling sites

Data was analyzed using One way Anova to compare each location with different land uses and concentration of $\mathrm{Fe}$ and $\mathrm{Mn}$, and fecal bacteria (concentration of Coliform and E. coli). All data then were compared to the standard created by the Decree of Health Minister of Indonesia (DHMI) No. 907 year 2002 [8] about drinking water quality requirements and The Regulation of Health Minister of
Indonesia (RHMI) No. 416 year 1990 [9] about Water Quality Standard. This is important to know whether the water is drinkable or not.

\section{RESUlTS AND DISCUSSION}

\section{A. The Content of Coliform and E. coli in Ground Water}

Most of groundwater at Ciracas sub-district was already contaminated by Coliform and E. coli (Table I). It was showed by the presence of Coliform and E.coli in groundwater which should be none of them was there (based on DHMI No. 907 year 2002). Coliform and E. coli were found at most of the study sites, except SG site. This showed that the groundwater was not able to be used as drinking water based on the standard of DHMI No. 907/2002 [8] and RHMI No. 416 year 1990 [9] which should be zero counts. Coliform and E. coli counts in groundwater ranged was from 18-26000 MPN/100 ml sample and 1,8-6790 MPN/100 ml sample. In Anova results, it showed significant difference in each land uses at study sites and concentration of Coliform and E. coli $(p<0.05)$. The highest Coliform concentration was in Ciracas subdistrict whereas Susukan sub-district with the highest E. coli concentration.

TABLE I: CONTENT OF COLIFORM AND E.COLI BACTERIA (MPN/100 ML

\begin{tabular}{|c|c|c|c|c|c|}
\hline Location & $\begin{array}{l}\text { Former } \\
\text { Land }\end{array}$ & Code & Coliform & E coli & Note \\
\hline \multirow{4}{*}{ Ciracas } & Swamp & $\mathrm{CS}$ & 26000 & 5150 & not drinkable \\
\hline & Rice & $\mathrm{CRF}$ & 475 & 330 & not drinkable \\
\hline & Garden & CG & 155 & 14 & not drinkable \\
\hline & Swamp & SS & 132 & 72 & not drinkable \\
\hline \multirow[t]{3}{*}{ Susukan } & $\begin{array}{l}\text { Rice } \\
\text { Field }\end{array}$ & SRF & 17620 & 6790 & not drinkable \\
\hline & Garden & SG & 0 & 0 & not drinkable \\
\hline & Swamp & $\mathrm{KrS}$ & 7300 & 1320 & not drinkable \\
\hline \multirow{3}{*}{$\begin{array}{l}\text { Kampung } \\
\text { Rambutan }\end{array}$} & Rice & $\mathrm{KrRF}$ & 18 & 13 & not drinkable \\
\hline & Garden & $\mathrm{KrG}$ & 12250 & 2200 & not drinkable \\
\hline & Swamp & $\mathrm{KdS}$ & 20 & 1.8 & not drinkable \\
\hline \multirow{3}{*}{$\begin{array}{l}\text { Kelapa } \\
\text { Dua } \\
\text { Wetan }\end{array}$} & Rice & $\mathrm{KdRF}$ & 5700 & 2000 & not drinkable \\
\hline & Garden & $\mathrm{KdG}$ & 1520 & 1800 & not drinkable \\
\hline & Swamp & $\mathrm{CbS}$ & 140 & 9.25 & not drinkable \\
\hline \multirow[t]{2}{*}{ Cibubur } & $\begin{array}{l}\text { Rice } \\
\text { Field }\end{array}$ & $\mathrm{CbRF}$ & 1950 & 330 & not drinkable \\
\hline & Garden & $\mathrm{CbG}$ & 515 & 64 & not drinkable \\
\hline
\end{tabular}

Water containing coli group was deemed to human feces contaminated. Contaminated water generally has high level of organic matters that contains many heterotrophic microorganisms. Heterotrophic microorganisms will use them for their metabolism process, such as Coliform bacteria [3], [10], [11].

The presence of Coliform and E. coli bacteria in each sample of ground water was assumed due to the densely populated residential area, where the distance of wells is in the adjacent with bathroom and septic tank. The distance should be $>10 \mathrm{~m}$ [12]. It was assumed that distribution of 
bacteria still occurred up to a distance of $11 \mathrm{~m}$, so that the distance should be at least $12 \mathrm{~m}$ [13]. In Ciracas sub-district, most of well and septic tank distance were not in accordance with the standard, only 6 wells were more than $10 \mathrm{~m}$ (Table II). Thus, it was found that most of groundwater at Ciracas sub-district was already contaminated by Coliform and E.coli bacteria in a high level. This also occured at South Jakarta district ranging from 3 to $160 \mathrm{MPN} / 100 \mathrm{ml}$ of E.coli [5].

TABLE II: DisTANCE OF WELL TO SEPTIC TANK

\begin{tabular}{|c|c|c|c|c|}
\hline Location & Well Type & $\begin{array}{c}\text { Age } \\
\text { (year) }\end{array}$ & $\begin{array}{l}\text { Depth } \\
\text { (m) }\end{array}$ & $\begin{array}{c}\text { Distance of Well to } \\
\text { Septic Tank (m) }\end{array}$ \\
\hline $\mathrm{CS}$ & Drilled & 23 & 20 & 10 \\
\hline CRF & Drilled & 14 & 12 & 8 \\
\hline CG & Excavated & 18 & 15 & 12 \\
\hline SS & Drilled & 22 & 30 & 20 \\
\hline SRF & Drilled & 10 & 15 & 11 \\
\hline SG & Drilled & 7 & 23 & 6 \\
\hline $\mathrm{KrS}$ & Drilled & 23 & 11 & 13 \\
\hline $\mathrm{KrRF}$ & Drilled & 3 & 11 & 10 \\
\hline $\mathrm{KrG}$ & Excavated & 20 & 20 & 7 \\
\hline $\mathrm{KdS}$ & Drilled & 2 & 30 & 20 \\
\hline KdRF & Drilled & 8 & 15 & 10 \\
\hline $\mathrm{KdG}$ & Drilled & 19 & 12 & 17 \\
\hline $\mathrm{CbS}$ & Drilled & 25 & 16 & 10 \\
\hline $\mathrm{CbRF}$ & Excavated & 25 & 15 & 5 \\
\hline $\mathrm{CbG}$ & Drilled & 37 & 15 & 7 \\
\hline
\end{tabular}

Dense settlements cause the difficulty to get the ideal distance of wells with septic tank for appropriate health requirements. The ideal distance of wells with septic tank sometimes can be fulfilled in one house, but it is not with neighbors's wells and septic tank distance. Nevertheless, there was no significant correlation between the distance of wells and septic tank with conscentration of Coliform and $E$. coli $(p>0,05)$. Kosasih et al [5] stated that well depth was statistically correlated with concentration of Coliform and E. coli. Harmayani and Konsukartha [7] was also mentioned the same condition at Banjar Ubung, Bali which was different from the result of this study. It assumed that contamination of well water from septic tank seepage was more reasonable for the presence of fecal bacteria. The other, sucking feces in septic tank regularly could reduce fecal bacteria counts.

\section{B. Iron and Manganese Concentration in Well Water}

It was known that only SG was not found bacteria contamination, although the well-septic tank distance was less than $11 \mathrm{~m}$. This could be caused by the former land of garden which contains more inorganic substances. As shown in Figure 2, SG had higher manganese concentration than other study sites, that was $2.25 \mathrm{mg} / \mathrm{L}$. According Bawahab and Isnawati [14], manganese was dissolved in oxygen-poor surface water. Thus, higher concentration of manganese might indicate less oxygen in water which microorganisms were difficult to grow eventually.

Almost $80 \%$ of study sites had $0.3 \mathrm{mg} / \mathrm{L}$ of Fe less than the standards of DHMI No. 907 year 2002 and RHMI No. 416 year 1990. Only 3 sites had higher Fe content in groundwater, SRF, KrRF, and KdRF which were not safe for consumption as drinking water. This could be due to the former land of rice field in those areas where contained a lot of inorganic substances derived from the use of pesticides and fertilizers during cultivation activities. If the inorganic compounds come into the aquatic environment, it will elevate the amount of metal ions in water [15], [16].

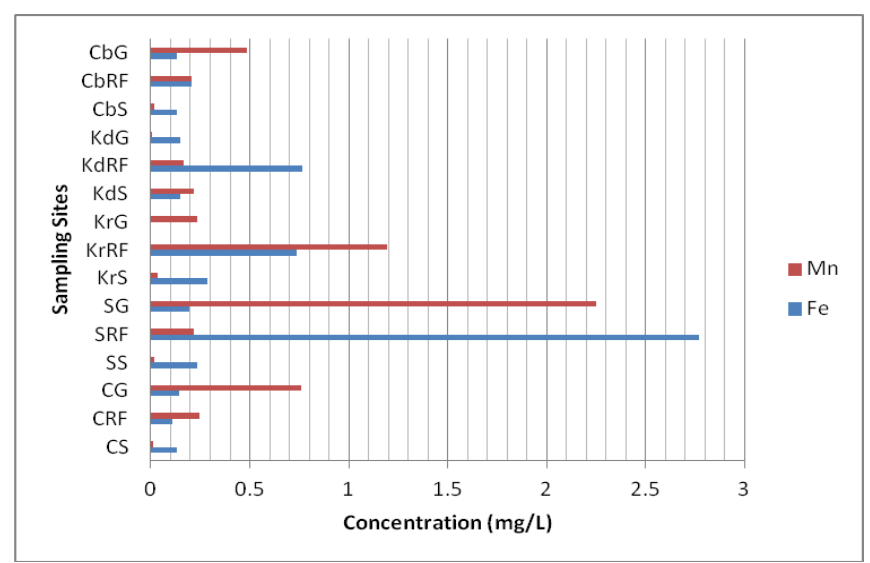

Fig. 2. Concentration of $\mathrm{Fe}$ and $\mathrm{Mn}$ in well water

Soluble iron at low $\mathrm{pH}$ can cause yellowing of the water, which causes stains on clothing and bacterial proliferation, namely Creonothrinx (iron bacteria). Therefore iron content should not exceed $1 \mathrm{mg} / \mathrm{L}$ as it can accelerate the growth of iron bacteria and can cause taste and odor in water (Sutrisno, 2004). Location SG had the highest Fe content (2.77 mg/L), and this can be explained why the water was slightly yellowish in color, smell and taste of iron metal.

Meanwhile, approximately $67 \%$ of wells contained high concentration of Mn that exceeds the standards of DHMI No. 907 year 2002 and RHMI No. 416 year 1990, which requires maximum concentration value of $0.1 \mathrm{mg} \mathrm{Mn} / \mathrm{L}$. Only 5 sites had lower concentration of $\mathrm{Mn}$ in groundwater. According to Sutrisno [3], if Mn concentration was greater than $0.5 \mathrm{mg} / \mathrm{L}$, it can cause a strange taste in drinking water and leave the chocolate-brown color of the clothes washing. For health, it is a toxic substance which can cause liver damage and respiratory disturbance.

The highest concentration of Mn was found in the former land of rice field and garden which was apparently derived from pesticides residues and fertilizers used during plantation activities [15]. While former swamp showed low concentration of $\mathrm{Mn}$ which was below the standard value $(0.1 \mathrm{mg} / \mathrm{L})$. This was apparently because of the large quantity of organic compouds which was easily degraded by microorganisms [11]. Therefore, the location of former swamp had large number of Coliform and E. coli (Table I).

The physical parameter such as $\mathrm{pH}$ and conductivity value also affected the concentration of $\mathrm{Fe}$ and $\mathrm{Mn}$. The result showed that there were 2 sites (SRF and KrRF) with lower value of $\mathrm{pH}$, below the standard of 6,5 , and high conductivity values, 0.71 and $0.73 \mathrm{~s} / \mathrm{cm}$. It could caused higher concentration of $\mathrm{Fe}$ and $\mathrm{Mn}$ due to leaching of metals and corrosion in water body [17]. The conductivity values in water can indicate the large number of metals that are 
dissolved in water [18]. Presumably this is other factor that led to higher concentration of Fe or $\mathrm{Mn}$ at both study sites.

Most of study sites contained iron and manganese. According to Bahawab and Isnawati [14], manganese and iron are metal substances widely encountered in the Earth's crust. Higher concentration of iron and manganese usually occur in the older and deeper wells. Because the deeper wells, the higher $\mathrm{CO}_{2}$ concentration and the lower $\mathrm{O}_{2}$ content, further it can be zero. This anaerobic condition will increase the solubility of $\mathrm{Fe}^{2+}$ and $\mathrm{Mn}^{2+}$ in ground water which resulting in increased iron and manganese in water [2]. Nevertheless, the results of this study showed the opposite. The older age wells (37 years) and the deeper wells $(30 \mathrm{~m})$ did not had the highest concentration of Fe and Mn. This could be caused by the interaction of microorganisms and organic materials in former land uses.

According to Darmono [19], metal content in water can be changed and highly dependent on the environment and climate condition. In rainy season, the metal content will be lower because the metal dissolution process. Whereas the metal content in the dry season will be higher because the metal becomes concentrated.

Groundwater contaminated with $\mathrm{Fe}$ and $\mathrm{Mn}$ should be treated to reduce the concentration of organic and inorganic compounds based on the standards. Drinking water use has to meet the standard of drinking water quality in order to avoid health problems. Contamination of fecal bacteria in drinking water has to be avoided by heating the water in 80 $100^{\circ} \mathrm{C}$ to kill bacteria. According to Alamsyah [20], chemical treatment for groundwater can be done through coagulation process using chemicals and aeration process. Other treatment is by physical methods, which are: 1) Filtering, 2) Precipitation, providing materials coagulant, 3) Absorption, using materials such as activated carbon to absorb the particles, and 4) Adsorption, the process of catching the ions contained in water.

\section{CONCLUSIONS}

Most of groundwater at Ciracas sub-district has been polluted by Coliform dan E. coli bacterias. Less location of Ciracas sub-district showed water contaminated by $\mathrm{Fe}$ and Mn. Therefore, based on microbial and chemical analysis, the groundwater in Ciracas sub-district was not safe for drinking water according to water quality standards of DHMI No. 907 year 2002 and RHMI No. 416 year 1990.

For drinking water use, the groundwater has to be boiled in $100^{\circ} \mathrm{C}$ pretreated to kill bacteria and filtration process to remove turbidity. The use of purchased treatment water (government drinking water treatment company) is recommended, although it is more expensive, but it is good for health. Nevertheless, the more important is to reduce population density and urbanisation to urban area, such as Jakarta. Besides, prevention and awareness is the best way to prevent ground water contamination. This can be achieved by individual and group actions of society so that groundwater is sustained and can be used by the next generation.

\section{ACKNOWLEDGEMENT}

We thank to Integrated Laboratory Centre, State Islamic University Syarif Hidayatullah Jakarta that give research facilities to collect data.

\section{REFERENCES}

[1] R. Achmad, Environmental Chemistry, Andi Offset, Yogyakarta, 2004.

[2] M. Raini, A. Isnawati and Kurniati, "Physical and chemical water quality of PAM in Jakarta, Bogor, Tangerang, and Bekasi Year 19992001," Media Research \& Health, vol. 14, no. 3, pp.14-19, 2004.

[3] T. Sutrisno, Water Supply Technology, Rineka Reserved, Jakarta, 2004.

[4] National Environmental Management Institution, Ground water quality: Status of ground water quality at Jakarta year 2004-2005. [Online]. Available: http://bplhd.jakarta.go.id/airlama.php

[5] B. R. Kosasih, Samsuhadi, and N. I. Astuty, "Ground water Quality at Tebet District South Jakarta through distribution pattern of Escherischia coli," JTL, vol. 5, no. 1, pp. 12-18, 2009.

[6] S. Suherman, "Degradation of ground water quality based on nitrate content in aquifier at Jakarta," Jurnal Riset Geologi dan Pertambangan, vol. 18, no. 2, pp. 61-68, 2008.

[7] K. D. Harmayani and I. G. M. Konsukartha, "Ground water pollution due to environmental waste disposal domestic in slums area," Journal of Housing Natah, vol. 5, no. 2, pp. 62-108, 2007.

[8] Decree of Health Minister of Indonesia No. 907 year 2002, Requirements and Quality Control of Drinking Water.

[9] Regulation of Health Minister of Indonesia No. 416 year 1990, Terms and Supervision of drinking water quality.

[10] U. Suriawiria, Water Microbiology, Alumni. Bandung, 1996.

[11] Mukono, "Basic Principles of Environmental Health," Airlangga University, Surabaya, 2000.

[12] National Standardization Agency, SNI 03-2398-2002: Planning Procedures for Septic Tank with Infiltration System, National Standardization Agency, Jakarta, 2002.

[13] R. Mulia, Environmental Health, Graha Ilmu,Yogyakarta, 2005. S. Alamsyah, Building Your Own Tools for Household Cleaning Water, Kawan Pustaka, Jakarta, 2008.

[14] N. Bawahab and A. Isnawati, "Picture on the Manganese Content of Water Resources Home Appliances in Greater Jakarta," World Mirror of Medicine, no. 135, pp. 47-50, 2002

[15] S. Hardjowigeno, Soil Science, Pressindo Academicians, Jakarta, 2007

[16] W. A. Wardhana, Impact of Environmental Pollution, Andi Offset, Yogyakarta, 1995.

[17] J. Soemirat, Environmental Toxicology, Gajah Mada University Press, Yogyakarta, 2003.

[18] I. D. A. Sutapa, "Well Water Quality Monitoring in the Village Karadenan Bogor Regency," Journal of Development studies, Community, \& Environment, vol. 2, no. 1, pp. 47-65, 2000.

[19] Darmono, Metals in Biological System of Living Organism, UI Press, Jakarta, 1995.

[20] S. Alamsyah, Building Your Own Tools for Household Cleaning Water, Kawan Pustaka, Jakarta, 2008. 